development of the staphylococcus pyogenes aureus, and that it is a specific disease and not merely traumatic periostitis which gives rise to death of the shaft. 2. The earliest symptoms appear in the juxta-epiphysial regions and spread thence inwarls to the medulla and outwards to the periosteum, assisted by the continuity of the latter with the epiphysial cartilage. To prove this point I made a series of experiments on young rabbits, and in the article in question full details are given. 3. In cases of total death of the diaphysis the destructive process is most marked at the extremities, the bone here being found ernicd and gangrenous; and further that there is such a loss that the dead shaft no longer fits accurately into the epiphysial and periosteal cap. You also remark that amputation seems to be the only treatment. With this I cannot agree, as the conclusion I came to was that operators must not merely be content with incising the periosteum and letting out the pus, but should attack the disease immediately at its root by tunnelling the juxta-epiphysial junction in addition, and so allow a sufficient exit for the products of the inflamed medulla.-I am, Sirs, yours faithfully,

$$
\text { A. H. TubBY, M.S. Lond., F.R.C.S. Eng. }
$$

Finsbury-circus, E.C., Nov. 1st, 1892.

\section{"ANALYSIS OF 10,000 CASES OF DISEASE AND DISTURBANCE OF THE EYES."}

\section{To the Editors of THE LANCET.}

SIRs, - The two instructive instances of unsuspected foreign oodies in the eye related by Mr. Brudenell Carter in his most interesting and practical article in THE LANCET of Oct. $29 \mathrm{th}$ recall to my mind one which was perilously near bringing me to unmitigated grief. A nervous young man came to consult me about "something in his eye." I examined him carefully but could detect nothing save violent purulent inflammation of the conjunctiva, and I told him so. It transpired that he had already consulted two medical men in London (where he lives) and that they both considered he was suffering from gonorrhoal ophthalmia, a diagnosis in which I was disposed entirely to agree, especially as I found he had still a troublesome gleet. I prescribed a lotion of boric acid and alum-being antiseptic to the backbone-which he seemed to think "dear at the price." My patient was going away, in no very amiable mood, when he turned at the door and said, "I know there's something in it!" "Come back, then, and let me have one more look." I seated him again in a good light, and, with the aid of a powerful pair of glasses (alas, presbyopic !), I was fortunate to discover, by the merest chance, a round black point almost hidden by a loose fold of mucous membrane, which had doubtless concealed it during the previous examinations. With a pointed pair of forceps I had no difficulty in extracting a long, round, sharp, black thorn quite half an inch in length and as thick at one end as o silver probe, which had been embedded in the loose tissue at the external angle of the eye and quite clear of the globe. When pressed for an explanation of its presence he told me that some three weeks previously he had scrambled through a hedge and a twig had struck the eye, but did not hurt it. As he left the consulting-room he muttered irefully, "What jolly fools doctors are!" Grateful !-Let me take this oppor tunity of adding my humble testimony to that of Mr. Brudenel Carter as to the efficacy of solution of nitrate of silver and the inefficacy of soothing antiseptic washes in the treatmen of ophthalmia neonatorum. This was, of course, the universally received teaching in my young days, but the rising generation are nothing if not germicidal. Without at all undervaluing antisepsis it sometimes, I confess, occurs to me that the almighty microbe is getting just a trifle too rampant and requires a little judicious "sitting on."

I am, Sirs, yours truly,

Chas. Egerton FitzGerald, M.D. St. And.

Folkestone, Oct. 29th, 1892

\section{CHLORIDE OF ETHYL: A WARNING.}

To the Eaitors of THE LANCET.

SIRs,-In THE LANCET of this week, under "New Inventions," Dr. Bengué's instrument for the administration of chloride of ethyl is spoken of in connexion with dental as well as other minor surgical operations. I write this note as a warning, as $I$ believe the inhalation of the vapour is not altogether free from danger. Having occasion to scarify a small patch of lupus erythematosus on the nose of a young lady, I thought it a favourable opportunity to try a chloride of ethyl tube. The spot was frozen well enough, but the patient turned pale, slightly livid and stopped breathing, looking very like a person under nitrous oxide gas. As I took away the ethyl at once she recovered in a few seconds, but I should certainly not use it again to any part of the face where it was possible that the vapour could be inhaled. Chloride of methyl applied by means of a tampon is far safer and easier, but care must be taken not to over-freeze the skin or a dermatitis may be set up.

I am, Sirs, yours faithfully,

Harley-street, W., Nov. 1st, 1892. H. RADCLIFFE Crocker.

\section{"MEDICAL AID ASSOCIATIONS."}

\section{To the Editors of THE LANCET.}

SIRS, - In the elucidation of this subject a specific instance of the working of one of these institutions is worth more than a great deal of generalisation. Having been medical officer for five years, from its inception, tó one of these associations, I am in a position to supply you and your readers with some particulars which may prove interesting. The Walsall Medical Aid Association was formed in 1885, and I was appointed its first surgeon at a salary of $£ 180$ a year, to be raised to $£ 200$ as soon as it was found to be a success. This was soon demonstrated, and in the course of twelve months or so the promise of a rise in my salary was fulfilled. By 1887 the Association had close on double the number of members it had at the beginning, and I thought I might now seek for a rise in salary. I may explain that, in addition to the fixed salary of $£ 200$ per annum, I had a house free, midwifery fees at 10s. 6d. each, with vaccination and teeth extraction. The midwifery cases did not quite average one a week. I was allowed one shilling a week from the committee, or paid that amount for the beating and lighting of the surgery, waiting. and consulting-rooms, while I had to pay the coal and gas account of the whole establishment-my house and the surgery \&c. being in the same building. When, then, the members had increased so much as to be nearly double, I applied (1887) to the committee for a little relief, which would be tantamount to a small rise in salary-viz., for them to take over and pay from their own account and thus relieve me of the coal and gas account of the whole establishment. I was refused and told that they regarded my position as very superior and that I ought to be content. I was then not in a position, by any means, to defy them, so I was forced to work away for over two years more, till 1889, until the members increased to close on 4500 , at the original fixed salary of $£ 200$, while all this time a handsome balance to the good was seen to be realised. Was I not, under these circum. stances, entitled to a rise? What did they want with the surplus; and by whose exertions was it earned? Fancy a surgeon to this association, that began with 1800 members and now had increased to 4500 or thereabout, only having the same salary for attending to the latter number as he had for attending the former! What can this be called but "sweating"? Furthermore, when the dispenser, who was having $\$ 60$ a year, asked for a rise with an increase in bis work he was refused and a junior qualified surgeon obtained in his stead, at a salary of $£ 100$ out-door, who, however, only remained a few months, as he could not get an adequate increase to induce him to stay; and when he was first appointed it was said to me that the management expected that now I had assistance in visiting I should be able to save in cab hire what it took to pay the junior surgeon over the former dispenser. What was all this ?--only an attempt to "sweat" the surgeons for the benefit of the estate of the association. The annual report of the year I left (1890) shows that for each member the surgeon was paid on an average $10 \frac{3}{4} d$., while each adult paid 3s. $6 d$. and each jurenile $2 s$. per annum. A quarter's contribution from each member went to pay the medical attendance, which is the primary object of these institutions, while the remaining three-quarters' contributions went for extraneous business, a large part of which, no doubt, was expected to be profit at the year's end out of the toil and labour and "sweat" of the unfortunate surgeon. Such has been the working of the Walsall Medical Aid Association from July 1st, 1885, until May 1st, 1890, while I was their medical officer. They had several changes after I left-two or three in the course of a 